\title{
Representing the 'other': the politics of nation and gender in R. K. Narayan's The Guide
}

\author{
Neluka Silva* \\ Department of English, Faculty of Arts, University of Colombo, Colombo.
}

\begin{abstract}
The Guide is regarded as R.K. Narayan's most celebrated and perhaps, his best work. While appreciating the lucid flow of the narrative and the underlying humour, this essay explores the female characters of Rosie and her motherin-law (Raju's mother), situating their representation within the discourses of nationalism, the former as the 'modern' hybrid woman and the latter as embodying the traditional.
\end{abstract}

From the outset, the two female characters of Rosie and Raju's mother are pitted against each other at the ends of two polar positions - tradition and modernity, signifying the debate of tradition vs modernity. Rosie is cast as a beautiful temptress who entices Raju and lures him into a life of decadence. As the narrative progresses, the westernised 'modern' character of Rosie becomes the binary opposite of the traditional Indian woman of the mother who proscribes the lifestyle of the 'public' woman.

As the hybrid 'other' to Raju's mother, in the representation of Rosie both race and gender collude to make her a character who 'corrupts' Raju. The ultimate tragedy that Rosie faces is not treated with sympathy but inscribes racial stereotypes serving to reinforce the nationalist underpinnings in the text of apportioning blame to the 'foreign' other.

Keywords: Nation, gender, tradition, modernity, respectability, individual identity

"We are viewed as public women..... we are not considered respectable, we are not considered civilized." (Narayan, 1958)

Rosie's statement to Raju is the starting point for the author's analysis of the politics of nation and gender in R. K. Narayan's widely acclaimed novel, The Guide. Hailed as a masterpiece, The Guide interweaves humour and pathos to chart the trajectory of the life of Railway Raju, who transforms himself from tour guide to spiritual guide (Narayan, 1958). Most critical readings of the novel centre on Raju, the protagonist, while the female characters are relegated to the background (Srinath, 1981; Ranchan \& Kataria, 1987; Kanaganayakam, 2005).

In this review, the characters of Rosie and Raju's mother are foregrounded to explore the way in which they are located within discourses of appropriate and inappropriate gender roles, which is complicated by the anti-colonial struggle which required India to re-envision the role of women in order to mobilise their support. The nationalist zeal, on the one hand, upheld everything that was construed as 'traditional' but, concomitantly, conflicted with the inevitable need for India to move towards modernisation. In discussing Indian nationalism, Chatterjee (1993) has argued that it was imperative to 'provide an answer to the new social and cultural problems concerning the position of women in "modern" society'. While the role of men within modern India was designed on similarities with the 'perceived forms of cultural modernity in the west', women were to be differentiated from the west by investing in them the 'political' function of safeguarding and fostering 'tradition'. The Indian conceptualisation of social space therefore is summed up by Chatterje (1993).

"The home in its essence must remain unaffected by the profane activities of the material world - and woman in its representation. And so one gets an identification of social roles by gender to correspond with the separation of social space into ghar and bahir."

It would seem that Indian nationalism added another layer to the dichotomisation of men and women's roles into the public and the private.

"The figure of woman often acts as a sign in discursive formations, standing for concepts or entities that have little to do with women in actuality. Each signification of this kind also implies a corresponding sign in which the figure 
of the man is made to stand for concepts or entities." (Chatterjee, 1993)

Chatterjee (1989) also notes that the nationalistic solution India presented to the Indian woman was to transform her into a 'new woman', unlike the memsaheb, by giving her access to education. But, despite the social upliftment of women through education, their education was designed to embrace and reinforce 'traditional' feminine virtues that would ensure their entrapment within the domestic sphere.

This review also explores how, within a post-colonial milieu of decolonisation, when the idea of 'India' is being reinforced, the kind of woman that Rosie represents is deployed and pitted against the 'traditional' woman, which in the narrative is Raju's mother and how initial connotations of westernisation (rendered through her name) are transformed so that she ends up in the narrative securing purchase as the 'ideal' woman and her traditional art becomes a symbol to uphold what is deemed to be 'national' culture.

Rosie transgresses these prescribed notions in many ways. Though she is subtly cast as the 'agent' for luring Raju into a life of dissolution at the initial stages of the narrative, her subject position undergoes several alterations through the trajectory of the narrative. She is clearly a victim of patriarchy - first through her marriage to Marco, her husband and later to Raju. However, this position is not immutable, as moments of ambiguity subvert the victim role and offer other possibilities within her modus operandi that enables her to secure agency at certain moments in the narrative.

She is introduced to the reader as the wife of Marco, a staid intellectual who does not allow his wife to indulge in temple dancing - the profession of her caste. Though educated with an MA in Economics, it appears that her husband married her because he was looking for an 'educated' woman. However, when Raju discovers her, she is deeply unhappy because the conservative Marco forbids her from continuing her dancing. Raju falls in love with her and persuades her to leave Marco. They embark on a relationship, which also turns into a business venture for Raju, who recognises the lucrative side of this pursuit and becomes her manager. In some instances in the narrative, she can be likened to a performing monkey who once again loses her individuality and is completely at the mercy of Raju's strategems. He manages her business, until his ambitions become excessive and ultimately falls prey to Marco's scheme to trap Raju and ends up in jail for two years. After he comes out of jail, without Rosie, he transforms himself to become a spiritual leader.

For the most part, Rosie is constructed to suit either Marco or later Raju's patriarchal anxieties. Her name, Rosie, conforms to a particular model of wifeliness that is anticipated from the intellectual, dry, Marco, and he has configured her to suit his temperament and expectations of a wife. The westernised name, though inscribing the dictates of the anglicised Marco, has particular connotations when it is confronted with 'tradition' as demonstrated when Rosie goes to Raju's house and encounters his mother.

The older woman, who epitomises the traditional Hindu woman, is visibly unsettled when she hears the westernised name and thus begins the antagonism.

“" "What's your name?" She asked kindly, and was rather taken aback to hear the name 'Rosie'. She expected a more orthodox name. She looked anguished for a moment, wondering how she was going to accommodate a Rosie in her home." (Narayan, 1958)

From this moment in the narrative the politics of 'tradition' are unveiled and determine relations within social and familial frameworks. As the embodiment of 'tradition', Raju's mother exposes the potency of deeprooted prejudice towards everything the younger woman embodies - in particular, modernity and westernisation. She is constructed as docile, religious, uneducated and confined within the domestic space of the home. The older woman's compliance in perpetuating patriarchal practices, such as the asceticism expected of a widow, affirms her ideological commitment to this value system through the explicit details of the Hindu traditions. One can argue that within the older woman's role as the self-sacrificing mother, is inscribed the anxieties of the decolonised nation. Her anxiety to safeguard the stability of the home at any cost signifies the "nurturance of national culture' which has to be achieved by building 'proper homes' (Lakshmi, 1996). Thus, even when her home is destabilised through the occupation of it by an 'outsider', Rosie, the onus of maintaining a facade of 'respectability' is placed upon the older woman. Respectability is linked to an idealistic vision of motherhood. One of the responsibilities conferred upon motherhood involves acting as the repository of tradition and maintaining the domestic sphere as the proper and rightful domain of the family. Such idealisations, as Sen (1993) explains, were and continue to be, based on,

"a general valorisation of motherhood as the creator and protector of the sanctuary of the 
home, as the good and chaste wife, and as the iconic representation of the nation derived from classical mythology."

As a result, women are policed by standards of 'respectability'. For instance, the attributes of 'true womanhood', by which a woman judges herself and is judged by society, are ascribed as the norm. The virtues of piety, purity, submissiveness and domesticity entrap women and dominant myths of femininity become a vehicle for mediating notions of female behaviour. 'Respectability' of the ideal woman is the counterpoint of the 'crude' and 'licentious' behaviour of the 'other' - in this case the temple dancer, while in contexts such as Sri Lanka, the woman of mixed ancestry or the ethnic 'other' (Tharu \& Lalita, 1993). Characters who refuse to comply with the majoritarian dictates are cast as rebellious and 'disobedient'.

The argument of modernity vs. tradition is forcefully and blatantly invoked by Raju's mother, and her allusions to the goddesses "Savitri, Sita and all the well-known heroines" (Narayan, 1958) are reproduced as the 'ideal' for the Indian woman. The capacity for endurance of pain and suffering revealed in the mother accentuates the qualities associated with certain religious icons in South Asia. Patience, acceptance and the ability to wait are identified with the goddess Sita. Indeed, the 'ideal' woman's behaviour may be seen to be an emulation of Sita herself. As Dube (2003) comments, the images of Sita and Savitri are posited as 'ideal wives who seek fulfilment through selfless service to their husbands'.

Viewed from the discourse of nationalism, 'traditional' gender roles offer purchase to the demands of the new nation. Tradition plays a determining role in nationalist politics and a vigorous critique, and nationalist vocabulary sets up an interdependence with tradition, myth and legend, and allocates a space for rehabilitating and reinforcing 'traditional' practices. One of nationalism's 'obligations', Sunder Rajan (1993) argues,

“... is developing an idiom which equates its discourses with a valorisation of the tradition because, by implication, tradition serves the need of promoting and safeguarding the ethnic identity of the community/nation."

Even in the new nation, what is evident here is that the Sita image continues to be played as a controlling motif in the ideological underpinnings of the cultural consciousness. While trying to disrupt its ideological hold on the mindset of the Indian woman, even
Indira Gandhi claimed that the mythical Sita was the "exemplary Indian woman" (Pouchpadass, 1981) "whose total identity is structured by a hierarchical authoritarian patriarchal system" (Gandhy \&Thomas, 1991). One of the attractions of the mythical figures for women is the perceived 'selfless' servitude, which Raju's mother also stresses in the narrative. These images are continually played out in the modern arena and according to Lau (2006) :

"The notion of acceptance being a sign of strength (especially on the part of the women), has long permeated the South Asian mentality, from mythologies which eulogise suffering as a virtue .... and grimly celebrate women who are wronged but who triumph by dint of patience and endurance."

Rosie's looks, confidence, education and seemingly liberal lifestyle become points of contestation between the two women, even if, according to Spivak (1994), Rosie's profession marks her as the 'subaltern' in the novel. Even if Narayan (1958) sanctions education for women, there is also a tacit approbation of the need to 'protect' and circumscribe women within the patriarchal system. While it is possible to read Rosie's attempt to defy the patriarchal system by securing an education and venturing out to perform in public, signifying her dissatisfaction with her state and necessitates breaking away from it, it is ineffectual since Narayan does not disrupt patriarchal ideals.

Though Rosie is authoritative on the subject of the temple dance rituals and their significance, for the most part she is denied voice or agency and what is demanded of her is to be the 'subservient' model wife. Spivak (1994) argues that Rosie is represented in a manner that marginalises her, but this reading focuses entirely on Rosie as the historically oppressed figure. According to Spivak (1994),

"If the subaltern - and the contemporary devadasi is an example - is listened to as agent and not simply as victim, we might not be obliged to rehearse decolonization interminably from above, as agendas for new schools of post-colonial criticism. But the subaltern is not heard. And one of the most interesting philosophical questions about decolonizing remains: who decolonizes, and how?"

As Kanaganayagam (2005) goes on to argue,

"it is not easy to disagree with Spivak. Her account of the tradition of temple dancing is, 
for the most part, accurate. Equally true are her comments about the oppression of temple dancers. That the novel does not choose to foreground the life of the dancer Rosie is also evident."

When Rosie is dancing publicly, Raju controls her every movement including her private associations. His ego reaches such proportions that, when she is at the peak of her career, he does not refer to Rosie, but arranges her engagements as though he is the performer, not the manager.

Thus the oppression of the subaltern is real and the text serves the limited purpose of providing the occasion to historicise marginalised figures. Rosie's position is predetermined by her caste and even though she has transgressed the limitations of this caste, by acquiring an education, she is not privy to the privileges of asserting her identity and individuality. In fact, identity as a construction that undergoes alterations during particular moments of patriarchal control is made manifest in the text. When Rosie is with Marco, her identity as a dancer is suppressed. Economic power derived from Marco subsumes her true profession. Raju, then supplants this authority and her identity goes through a further mutation. He decides she must resume her profession, but these are transacted on his terms, for instance, her name has to be changed.

"Rosie is a silly name. ... The trouble with you is that although your people are a traditional dance family, they didn't know how to call you. For our public purpose your name must be changed. ... It's not a sober or sensible name. If you are going to appear before the public with that name, they will think it's someone with cheap tricks." (Narayan 1958)

This episode not only reveals the politics of the heterosexual relationship, but also the dictates of the nation, which, in order to recoup its 'cultural traditions' such as temple dance, it can only be enacted by subscribing to certain hegemonic constructions of name and image.

Although they are not legally married, as Raju reveals, they behave as husband and wife. In the conventional marriage, the change of a woman's name is customary. Here too, the name change can be read as a symbolic enactment of the relinquishing of identity that is transacted in marriage. Along with the name, other facets of Rosie's personality are also changed after her 'marriage' to Raju. She adopts a more traditional role configured through dress and behaviour.
"She had tied her hair into a knot, decorated her forehead with a small vermillion dot, lightly sprinkled a little powder on her face, and clad herself in a blue cotton sari." (Narayan, 1958)

At this stage of her life with Raju, Rosie is denied the power to make her own decisions and this is particularly palpable in the manner in which financial matters are solely within Raju's ambit. She does not show interest in the business side of her profession and her sole concern is to keep dancing and in adopting the traditional persona. Hence, the reader is lulled into a state of thinking that Rosie has conformed to the role of 'wifely duty'.

However, it is not only the trope of wife that gets stressed in the narrative, Narayan appears to be working with several cultural tropes - the householder, the wife, the dancer, and the renouncer, all of which have a certain purchase within the national project. All these are literary tropes and cultural and national markers (Kanaganayagam, 2005). Raju's involvement with Rosie violates several codes and the text deliberately makes her a married woman to problematise her role and her position in the house, as wife reveals the politics of marriage. Though this may not be intentional on the part of the writer, what Rosie's character represents is what Mohanty (1993) describes as,

"the way women are constituted as a group via dependency relationships, vis-à-vis men who are implicitly held responsible for these relationships."

By the same token, Raju's act of establishing Rosie in his home makes him a de facto householder, although his position of authority gets diffused and is tenuous at the moment when Rosie's status as a dancer rises and Raju has to relinquish authority. This may be read as a symbolic enactment of the transfer of power from one party to another in the national narrative. Rosie seizes agency when she becomes famous. She starts fraternising with dancers and musicians, and when Raju tries to intervene, she refuses to act as the acquiescent wife. For instance, in one episode, when he demands how long the musicians are going to stay in the house, she replies peremptorily, "I like their company, how can I tell them to go." Protest as he might, Raju becomes helpless and admits "I could do nothing about it." (Narayan, 1958)

Later, Rosie's disavowal of her relationship with Raju also marks a rupture in the subject position of the dutiful 'wife' figure that she occupied in the early stages of the narrative. When Raju's forgery leads to his arrest, though her initial reaction seems to be 
marked by received notions of female behaviour, she then takes control of the situation, so that he feels like a "hanger on" in the house, while "she became hardened" (Narayan, 1958). Economic independence, coupled with his misdemeanour, grants her the confidence to make the decision to leave him once she helps him. She invests all her energy in hiring the best lawyer and getting him out of prison. As the impetus to release him increases, he becomes more and more helpless, watching the scenario from the sidelines, as though he is part of an elaborate play. It can be inferred that domestic and public spaces are configured very carefully in the text, expressing social and economic hierarchies. However, the original hierarchy is no longer valid, and power relations shift according to circumstance.

Women's agency could be defined as the ability of a woman to "assert her own needs or to assert her dissatisfaction with the limitations placed on her" (George, 1996) and thus effect a change in her situation. It is this moment of independence that impels Rosie to continue her career casting aside the shackles of male power. After the court case, though it is anticipated that she will go back to Marco, instead she embarks her career on her own. Her subsequent success and the prominence she acquires both for herself and her art reveal that her art is appropriated to become a part of India's attempt to rehabilitate its traditional practices and is firmly located within the cultural repertoire.

As Kanaganayagam (2005) notes, though the novel does not choose to foreground the life of the dancer, there is obviously a need to read it with the kind of sensitivity that recognizes the structures of a system that marginalize those who are powerless, but also to recognise that Rosie is not entirely devoid of agency in the novel. The Guide cannot be read without an acknowledgement of its complicity with modernity. Even the most perfunctory reading of the novel would alert the reader to the colonial and neocolonial dimension of the novel and Rosie's changing role in the configuration. In most instances, when women are portrayed, they rarely cross the boundaries of the domestic. In the event that they do so, they are portrayed in simplistic terms and are largely as heroines. The pattern that emerges in this novel can be made analogous to Mankekar's (1999) exploration of the role of women in 'Tamas'. She argues that it is a pattern set up by patriarchal history in depicting women as either helpless observers/victims or courageous heroines.

"Although discourses of gender are constantly reconfigured in terms of the contingencies of the present, it is not surprising that colonial representations of women in terms of this dichotomy have found their way into postcolonial nationalist discourse." (Mankekar, 1999)

Thus, though Narayan's work has been regarded as deeply traditional, as Ashcroft et al. (1989) argue,

"the post-colonial text is always a complex and hybridised formation, and the reconstruction of 'pure' cultural value, is always conducted within a radically altered dynamic of power relations."

Even if the focal point in Narayan's story is that of Raju, it offers the reader a nuanced portrayal of Rosie, unveiling the problematic, of female subjectivity and identity. Though she is yoked to patriarchal structures and power relations, there are indications that she transcends the bounds of these structures and establishes herself as a dancer of repute. It is for this reason that she makes an interesting case for analysis, reminding us that though her role is culturally predetermined she can negotiate a space for recognition and autonomy. In the midst of a dialectic between the collective of family and marriage, there are independent individuals like Rosie whose social inflection is one of the strongest marks left by the colonial project and europeanisation (Ashcroft et al., 1989).

When she adopts the identity of 'Nalini', she discards her 'private' image and dependency on man and instead, becomes a career woman and the middleclass, non-hereditary dancer. Here it is simplistic to view her entirely as a victim, for she appropriates agency to distinguish herself as an artist without any need of a man (Chambers, 2005). Thus, Nalini is an individual who carves out her space within the national frame, where the post-colonial landscape valorises and validates 'traditional' art forms and appropriates these forms to promote the 'authentic' and essentialist within the nationalist discourse. Characters like Rosie, despite being marginalised within these discourses can be inscribed within them to serve the national agenda. Even if he fails to present a female character who embodies a positive intermingling of tradition and modernity, her advancement in both status and economic power marks Narayan's ambivalence and reveals the social and cultural formations that problematise reading this character through rigid parameters:

"Nalini's photograph, the name of the institution where she was performing and the price of the tickets. Now at this corner of South India, now there, next week in Ceylon and another week in 
Bombay or Delhi. Her empire was expanding rather than shrinking. It filled me with gall that she should go on without me." (Narayan, 1958)

\section{ACKNOWLEDGEMENT}

The author is most grateful to Pavithra Tantrigoda for her input into the conceptualisation of some issues in this article and enabling the author to logically structure it.

\section{REFERENCES}

Afzal-Khan, F. (1993) Cultural imperialism and the IndoEnglish novel: genre and ideology in R. K Narayan, Anita Desai, Kamala Markandaya and Salman Rushdie. Philadelphia: Penn State Press.

Ashcroft, W. D., Griffiths, G. \& Tiffin, H. (1989) The Empire writes back: theory and practice in post-colonial literatures, London, New York: Routledge.

Atkinson, D. W. (1987) Spiritual Growth in the Fiction of R. K. Narayan, Journal of South Asian Literature, 22 (2), pp: 16-27.

Chambers, C. (2005) Purity of the classical forms': sexuality, gender and Bharatanatyam in texts from South India, Moving Worlds, 5(2), pp: 74-87.

Chatterjee, P. (1989) Colonialism, nationalism and colonized woman: the contest India, American ethnologist, 16(4), pp: 622-663, [online] Available at: <http://www.jstor.org/ stable/645113> [Accessed October 2011]

Chatterjee, P. (1993) The Nation and Its Fragments, New Jersey: Princeton University Press.

Dube, L. (2003) Caste and woman, In A. Rao ed. 2003. Gender and Caste, New Delhi: Kali for Women.

Gandhy, B. \& Thomas, R. (1991) Three Indian film stars, In C. Gledhill ed. Stardom: industry of desire, London and New York: Routledge, pp: 107-131.

George, R. M. (1996) The politics of home: postcolonial relocations and twentieth-century fiction, Cambridge; Cambridge University Press.

Kanaganayakam, C. (2005) How to teach The Guide as a culturally different text, Post Colonial Text, 1(2) [online] Available at: <http://www.postcolonial.org/index.php/pct/ article/view/337/485> [Accessed October 2011]
Lakshmi, C. S. (1996) Bodies called women: some thoughts on gender, ethnicity and nation, (unpublished paper- cited with permission from the author).

Lau. L. (2006) The new Indian woman: who is she, and what is 'new' about her?, Women's Studies International Forum, 29(2), pp: 159-171, [online] Available at: < http://www.sciencedirect. com/science/article/pii/S0277539506000033> [Accessed October 2011]

Mankekar, P. (1999) Screening culture, viewing politics: an ethnography of television, womanhood and nation in postcolonial India, Durham and London: Duke University Press.

Mohanty, C. T. (1984) Under western eyes: feminist scholarship and colonial discourses, In P. Williams \& L. Chrisman (eds.) 1993, Colonial discourse and post-colonial theory, London: Harvester Wheatsheaf, pp: 196-220.

Narayan, R. K. (1958) The Guide, London: Penguin.

Pouchpadass, E. (1981) Indira Gandhi: my truth, Delhi: Vision.

Ranchan, S. P. \& Kataria, G. R. (1987) Transformation via the Feminine in R. K. Narayan's Krishnan, Raju and Jagan, Journal of South Asian Literature, 22(2) pp: 5-15, [online] Available at: < http://www.jstor.org/discover/10.2307/408729 56 uid $=369191861$ \&uid $=3738456$ \&uid $=2$ \&uid $=3$ \&uid $=67 \&$ uid $=369191791 \&$ uid $=62 \&$ sid $=21106558007283>$ [Accessed October 2011)

Sen, S. (1993) Motherhood and mothercraft: gender and nationalism in Bengal, Gender and History, 5(2) pp: 231-243.

Silva, N. (2004) The gendered nation: contemporary writings from South Asia, Delhi: Sage.

Spivak, G. C. (1994) How to Read a 'Culturally Different Book', In F. Barker, P. Hulme \& M. Iversen. (eds.) Colonial Discoursel Postcolonial Theory, Manchester: Manchester University Press, pp: 126-150.

Srinath, C. N. (1981) R. K. Narayan's comic vision: possibilities and limitations, World Literature Today, 55(3) (Summer), pp: 416-419.

Sunder Rajan, R. (1993) Real and imagined women: gender, culture and post-colonialism, London and New York: Routledge.

Tharu, S. \& Lalita, K. (eds.) (1993) Women writing in India Vol 2: the twentieth century, London: Pandora. 